\title{
FREQUENCY OF FUNGAL MYCOFLORA ON RICE
}

\section{MUHAMMAD ASIF ILYAS $^{1 *}$, FAZAL UR REHMAN ${ }^{1}$, AFTAB SULTAN $^{1}$, IMRAN ILYAS ${ }^{2}$, IQRA ILYAS ${ }^{3}$, HASNAIN ALI ${ }^{4}$}

${ }^{1}$ Department of Plant Pathology, College of Agriculture, University of Sargodha, Pakistan. ${ }^{2}$ Institute of Food Science and Technology, University of Sargodha, Pakistan. ${ }^{3}$ Department of Environmental Sciences, Women University Multan, Pakistan. ${ }^{4}$ Department of Agronomy, College of Agriculture, University of Sargodha, Pakistan. Email: masifilyas447@gmail.com

Received: 09 February 2021, Revised and Accepted: 07 March 2021

\section{ABSTRACT}

Introduction: Rice (Oryza sativa L.) is the second best essential cereal crop of the world as well as of Pakistan. There are various fungal pathogens that attack on rice and cause various rice diseases.

Methods: Therefore, the present experiments were done to isolated different fungi associated with seeds, stems, and leaves of commercially grown rice varieties and of mainly isolated species.

Results: Several fungi, namely, Magnaporthe oryzae, Curvularia lunata, Helminthosporium oryzae, Fusarium moniliforme, Alternaria alternata, Nigrospora oryzae, and Aspergillus niger were isolated from seeds, stems, and affected leaves of rice.

Conclusion: In our research, the frequency of fungal mycoflora on rice has been calculated and the maximum isolates of Fusarium spp. have been found. Keywords: Oryza sativa; Fungal Diseases; Frequency; Mycoflora; Colonization.

(C) 2021 The Authors. Published by Innovare Academic Sciences Pvt Ltd. This is an open access article under the CC BY license (http://creativecommons.org/ licenses/by/4.0/) DOI: http://dx.doi.org/10.22159/ijls.2021v9i2.41045. Journal homepage: https://innovareacademics.in/journals/index.php/ijls

\section{INTRODUCTION}

Rice (Oryza sativa L.) is the second best essential cereal crop of the world [1]. It is staple food for more than half of the world's population. About $90 \%$ of global rice production is contributed by Asia continent alone. Rice is also essential staple food and cash crop of Pakistan [2]. Rice crop is exposed to attack of 50 diseases that including 6 bacterial, 21 fungal, 4 nematodes, 12 viral, and 7 miscellaneous diseases and disorders. Rice $(O$ sativa $\mathrm{L}$ ) is the most extensively grown cereal crop cultivated in more than 147 million hectares, worldwide [3]. Rice seed is known to be colonized by several genera of fungi, among which many are identified as plant pathogens. The infected seed not only affects the quality of the grain but also spreads the seed-borne pathogens to different regions. Rice is known to be attacked by 56 fungal pathogens [4] out of which 41 are reported as seed borne. It is described a number of fungal species on rice accountable for grain staining. In the Philippines, 70 fungi as seed-borne fungi have been reported on rice. A broad list of fungi correlated with rice seed is given in Table 1 . There are various seed-borne pathogens in agriculture [5]. The seed-borne fungi have been grouped into diverse classifications by many workers as field and storage fungi [6] obligate parasites, facultative saprophytes, and facultative parasites or saprophytes and parasites. In this research article, various fungal pathogens attacking on rice have been given. Most fungi identified on rice are either.

I. Pathogenic fungi (causing characteristic disease symptoms)

II. Deleterious fungi (normally do not cause any disease but affect rice quality in storage, seed germination, and cause seed rot).

The best haulers of several pathogens are seeds which are responsible for maximum plant diseases prominent to huge loss of crop yield [7]

Table 1: Colonization $\%=$ Number of seeds $/$ pieces colonized by a fungus $\times 100$

\begin{tabular}{llll}
\hline S. No. & Plant part & Number of sample & Number of fungi isolated \\
\hline 1. & Panicles & 5 & 10 \\
2. & Stem & 9 & 13 \\
3. & Leaf & 17 & 14 \\
\hline
\end{tabular}

Rice crop is well known to be attacked by many seed-borne fungal diseases of major and minor importance. Some of these are extensively disseminated causing significant yield as well as economic loss particularly blast, brown spot, and bakanae disease [8]. A few have restricted scattering and are of negligible importance, but becoming increasingly famous in recent years (leaf scald, sheath rot, false smut, and kernel smut). However, rice blast, brown spot, bacterial leaf blight and leaf streak, sheath blight, sheath rot, Fusarium wilt or Bakanae, stem rot, Tungro virus, false smut, and post-harvest disease are main diseases attacking on rice. At any growing stage of rice plant, the rice blast disease can attack and also may infect rice grains after harvest, causing significant losses in equally quality and quantity of the produce [9]. A filamentous cause rice blast, ascomycete fungus Magnaporthe oryzae (syn: Pyricularia oryzae Cav.) is an infectious fungal disease which is spread worldwide and predominant in more than 85 countries of the world. Blast disease occurs in a wide range

Table 2: No. of Counts of Mycoflora on Rice

\begin{tabular}{lll}
\hline S. No. & Fungal spp. & Count \\
\hline 1 & Aspergillus niger & 3 \\
2 & Fusarium & 6 \\
3 & Aspergillus flavus & 1 \\
4 & Cercospora & 2 \\
5 & Hemicola & 2 \\
6 & Nigrospora & 4 \\
7 & Anonymous & 2 \\
8 & Bipolaris & 2 \\
9 & Rhizoctonia & 1 \\
10 & Curvularia & 4 \\
11 & Chlamydosporium & 1 \\
12 & Alternaria & 2 \\
13 & Alternaria alternata & 1 \\
14 & Fusarium graminearum & 1 \\
15 & Phoma & 1 \\
16 & Arthrobotrys & 1 \\
17 & Pyricularia & 1 \\
\hline
\end{tabular}


Table 3: Percentage of mycoflora on different parts of rice plant

\begin{tabular}{|c|c|c|c|c|c|}
\hline S. No. & Sample code & Name of fung(sp.) & Leaf & Stem & Panicles \\
\hline \multirow[t]{6}{*}{1.} & 435 & Aspergillus niger & $5.5 \%$ & & \\
\hline & & Fusarium & $5.5 \%$ & & \\
\hline & & Aspergillus flavus & $5.5 \%$ & & \\
\hline & & Cercospora & $11.11 \%$ & & \\
\hline & & Hemicola & $27.8 \%$ & & \\
\hline & & Nigrospora & $44.44 \%$ & & \\
\hline \multirow[t]{6}{*}{2} & 434 & Anonymous & $16.67 \%$ & & \\
\hline & & Bipolaris & $8.3 \%$ & & \\
\hline & & Nigrospora & $25 \%$ & & \\
\hline & & Curvularia & $8.3 \%$ & & \\
\hline & & Fusarium & $25 \%$ & & \\
\hline & & Alternaria & $16.67 \%$ & & \\
\hline \multirow[t]{7}{*}{3} & 395 PR & Anonymous & & $17 \%$ & \\
\hline & & Nigrospora & & $31.03 \%$ & \\
\hline & & Rhizoctonia & & $24.13 \%$ & \\
\hline & & Fusarium & & $6.89 \%$ & \\
\hline & & Curvularia & & $6.89 \%$ & \\
\hline & & Hemi cola & & $6.89 \%$ & \\
\hline & & Chlamydosporium & & $6.89 \%$ & \\
\hline \multirow[t]{3}{*}{4} & 395 PR & Fusarium & $42.30 \%$ & & \\
\hline & & Hemicola & $30.70 \%$ & & \\
\hline & & Nigrospora & $27 \%$ & & \\
\hline \multirow[t]{2}{*}{5} & $431 \mathrm{PR}$ & Nigrospora & $40 \%$ & & \\
\hline & & Cercospora & $60 \%$ & & \\
\hline \multirow[t]{2}{*}{6} & 422 & Nigrospora & $64.70 \%$ & $64.70 \%$ & \\
\hline & & Aspergillus niger & $35.25 \%$ & $35.25 \%$ & \\
\hline \multirow[t]{5}{*}{7} & 433 & Aspergillus niger & $18.51 \%$ & $18.51 \%$ & \\
\hline & & Nigrospora & $18.51 \%$ & $18.51 \%$ & \\
\hline & & Fusarium & $25.92 \%$ & $25.92 \%$ & \\
\hline & & Chlamydosporium & $18.51 \%$ & $18.51 \%$ & \\
\hline & & Alternaria alternata & $18.51 \%$ & $18.51 \%$ & \\
\hline \multirow[t]{5}{*}{8.} & 404-PR & Aspergillus & $3.4 \%$ & & \\
\hline & & Nigrospora & $44.82 \%$ & & \\
\hline & & Bipolaris & $17.24 \%$ & & \\
\hline & & Cercospora & $17.24 \%$ & & \\
\hline & & Fusarium & $17.24 \%$ & & \\
\hline \multirow[t]{3}{*}{9.} & 1-SD-R & Fusarium & $25 \%$ & & \\
\hline & & Aspergillus & $37.5 \%$ & & \\
\hline & & Nigrospora & $37.5 \%$ & & \\
\hline \multirow[t]{4}{*}{10} & 438 & Fusarium & & $54.16 \%$ & $54.16 \%$ \\
\hline & & Aspergillus & & $4.16 \%$ & $4.16 \%$ \\
\hline & & Alternaria & & $20.83 \%$ & $20.83 \%$ \\
\hline & & Nigrospora & & $20.83 \%$ & $20.83 \%$ \\
\hline \multirow[t]{4}{*}{11.} & 437 & Nigrospora & $35.71 \%$ & $35.71 \%$ & \\
\hline & & Aspergillus & $32.14 \%$ & $32.14 \%$ & \\
\hline & & Alternaria & $17.85 \%$ & $17.85 \%$ & \\
\hline & & Rhizoctonia & $32.14 \%$ & $32.14 \%$ & \\
\hline 12. & 412 & Fusarium & & $26.53 \%$ & $26.53 \%$ \\
\hline & & Nigrospora & & $16.33 \%$ & $16.33 \%$ \\
\hline & & Aspergillus & & $25.53 \%$ & $25.53 \%$ \\
\hline & & Arthrobotrys & & $16.33 \%$ & $16.33 \%$ \\
\hline & & Cercospora & & $4.08 \%$ & $4.08 \%$ \\
\hline & & Rhizoctonia & & $4.08 \%$ & $4.08 \%$ \\
\hline & & Curvularia & & $6.12 \%$ & $6.12 \%$ \\
\hline 13. & 411 & Aspergillus & $10.25 \%$ & & \\
\hline & & Rhizoctonia & $10.25 \%$ & & \\
\hline & & Bipolaris & $10.25 \%$ & & \\
\hline & & Alternaria & $15.38 \%$ & & \\
\hline & & Chlamydosporium & $15.38 \%$ & & \\
\hline & & Nigrospora & $23.07 \%$ & & \\
\hline & & Curvularia & $15.38 \%$ & & \\
\hline 14 & $11=$ Sindh & Nigrospora & $35.48 \%$ & $35.48 \%$ & \\
\hline & & Fusarium & $29.03 \%$ & $29.03 \%$ & \\
\hline & & Curvularia & $19.35 \%$ & $19.35 \%$ & \\
\hline & & Bipolaris & $16.12 \%$ & $16.12 \%$ & \\
\hline & 420 & Fusarium & $20 \%$ & & \\
\hline & & Pyricularia & $20 \%$ & & \\
\hline & & Fusarium & $20 \%$ & & \\
\hline & & graminearum & & & \\
\hline & & Aspergillus niger & $40 \%$ & & \\
\hline
\end{tabular}


Table 3: Percentage of mycoflora on different parts of rice plant (Continued)

\begin{tabular}{|c|c|c|c|c|c|}
\hline S. No. & Sample code & Name of fung(sp.) & Leaf & Stem & Panicles \\
\hline \multirow[t]{3}{*}{16} & 41New R & Fusarium & & $50 \%$ & \\
\hline & & Anonymous & & $28.57 \%$ & \\
\hline & & Aspergillus & & $21.42 \%$ & \\
\hline \multirow[t]{3}{*}{17} & 414 & Nigrospora & $29.16 \%$ & & \\
\hline & & Fusarium & $20.83 \%$ & & \\
\hline & & Arthrobotrys & $50 \%$ & & \\
\hline \multirow[t]{5}{*}{18} & 433 & Nigrospora & $28 \%$ & & $28 \%$ \\
\hline & & Fusarium & $20 \%$ & & $20 \%$ \\
\hline & & Curvularia & $14 \%$ & & $14 \%$ \\
\hline & & Alternaria & $22 \%$ & & $22 \%$ \\
\hline & & Bipolaris & $14 \%$ & & $14 \%$ \\
\hline \multirow[t]{6}{*}{19} & 403 & Fusarium & $31.7 \%$ & & \\
\hline & & Aspergillus & $14.6 \%$ & & \\
\hline & & Bipolaris & $7.3 \%$ & & \\
\hline & & Nigrospora & $29.26 \%$ & & \\
\hline & & Hemicola & $7.3 \%$ & & \\
\hline & & Curvularia & $12.19 \%$ & & \\
\hline \multirow[t]{3}{*}{20} & 429 & Fusarium & $40 \%$ & & \\
\hline & & Nigrospora & $40 \%$ & & \\
\hline & & Chlamydosporium & $20 \%$ & & \\
\hline \multirow[t]{4}{*}{21} & 2-Sindh R & Aspergillus & & & $50 \%$ \\
\hline & & Curvularia & & & $16.6 \%$ \\
\hline & & Fusarium & & & $16.6 \%$ \\
\hline & & Alternaria & & & $16.6 \%$ \\
\hline \multirow[t]{5}{*}{22} & 436 & Phoma & $6.8 \%$ & & \\
\hline & & Fusarium & $27.58 \%$ & & \\
\hline & & Curvularia & $44.82 \%$ & & \\
\hline & & Cercospora & $10.3 \%$ & & \\
\hline & & Aspergillus & $10.3 \%$ & & \\
\hline \multirow[t]{3}{*}{23} & 400 & Bipolaris & & $30.3 \%$ & $30.3 \%$ \\
\hline & & Fusarium & & $45.45 \%$ & $45.45 \%$ \\
\hline & & Nigrospora & & $30.30 \%$ & $30.30 \%$ \\
\hline
\end{tabular}

\section{Number of Sample}

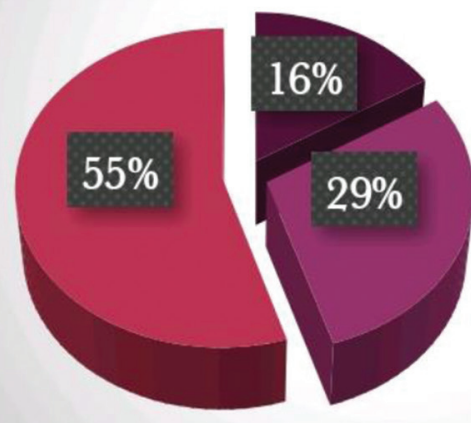

Panicles

- Stem

Leaf

Graph 1: Percentage of Mycoflora on Different Parts of Rice plants

of climatic conditions from temperate to tropics [10] and by wind the pathogen is spread and by infected plant debris or seeds left in the fields the pathogen dispersed. At any stage of growth, rice blast can be seemed and produced various symptoms [11]. In different parts of the world, numerous rice blast epidemics have occurred, resulting in yield losses in these areas ranging from $50 \%$ to $90 \%$ of the expected crop. Yield losses due to blast prolonged from $1 \%$ to $50 \%$ in diverse rice growing regions of the world dependent on the type of cultivar grown and ecological conditions flourished under normal situations. However, heavy losses are caused by the various diseases under favorable ecological conditions and production may reach up to $90 \%$.

In this research work, mycoflora of various fungal pathogens attacking on rice has been studied.

\section{METHODS}

\section{Surveillance and samplings}

Diseased samples containing of seeds, stems, and leaves of various rice varieties were collected from different locations including district Narowal-Muridike Rd, Sialkot, Punjab, Pakistan $\left(32^{\circ} 04^{\prime} 06.7^{\prime \prime}\right.$ E, $74^{\circ} 33^{\prime} 48.4^{\prime \prime}$ E), Nankana Sahib, Punjab, Pakistan $\left(31^{\circ} 21^{\prime} 06.8^{\prime \prime} \mathrm{N}\right.$, $73^{\circ} 45^{\prime} 52.6^{\prime \prime}$ ), and Bhai Pheru-Mur Khunda Rd, Nankana Sahib, Punjab, Pakistan $\left(31^{\circ} 15^{\prime} 49.9^{\prime \prime} \mathrm{N}, 73^{\circ} 50^{\prime} 10.5^{\prime \prime} \mathrm{E}\right)$. These samples were placed into paper bags and were properly labeled and taken back into the laboratory for isolation of different disease causing fungi.

\section{Surface sterilization}

The affected seeds, stems, and leaves were disinfected with 5\% commercial bleach (sodium hypochlorite) for 1-1.5 min and then put into decontaminated Petri dishes comprising freshly prepared potato dextrose agar (PDA) medium. Then, the rice samples were furthermore cut into minor portions such as leaf samples were cut into $0.5 \mathrm{~cm}^{2}$ pieces, whereas, stems and panicles samples were cut into $0.5-1.0 \mathrm{~cm}^{2}$.

\section{Inoculation}

Five seeds/pieces of diseased plant parts were placed in each Petri dish. These Petri dishes were incubated at $25^{\circ} \mathrm{C}$ for 5 days to induce sporulation of the fungi. Different fungal colonies were appeared, which were purified and multiplied on PDA. The isolated fungal species were identified on the basis of their morphological characteristics through microscopy. The data on frequency of isolated fungi from seeds, stems, and leaves of different rice various varieties were recorded.

\section{RESULTS AND DISCUSSION}

\section{Identification and classification}

Usually, fungal documentation is done on the basis of morphological features of the collection, conidia, and conidiogenous cells. Here, in this research, the fungi were categorized by the progress of spores, 


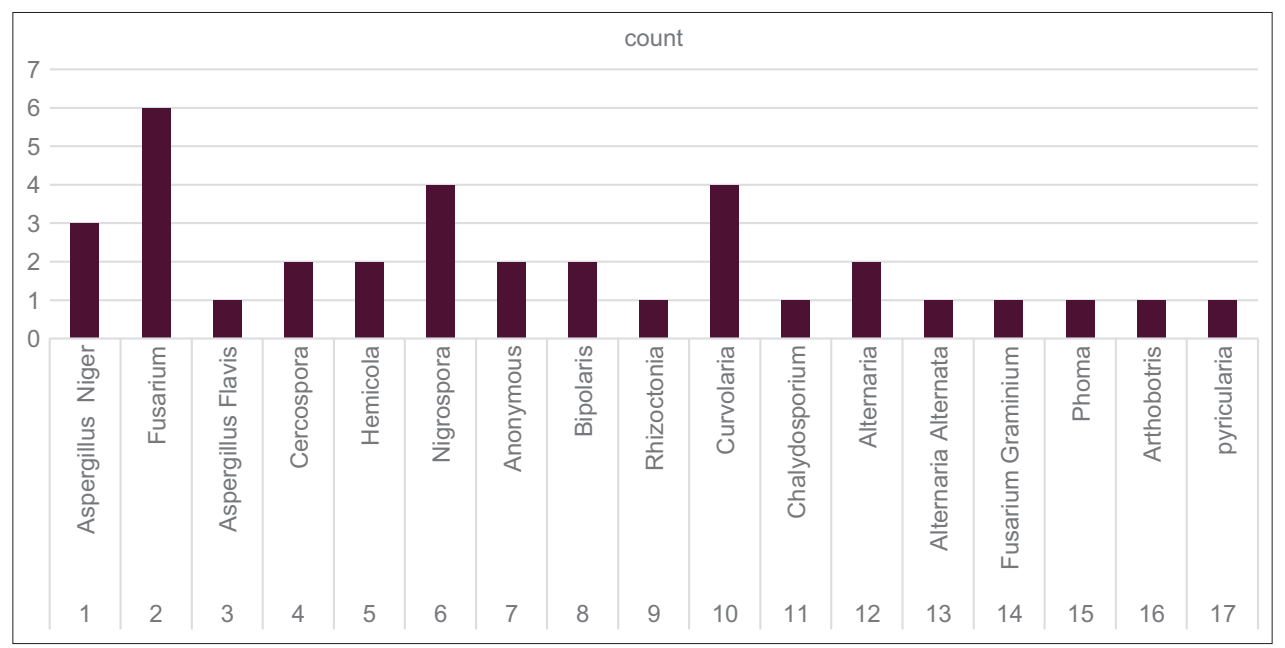

Graph 2: Counts of Different Pathogen on Rice

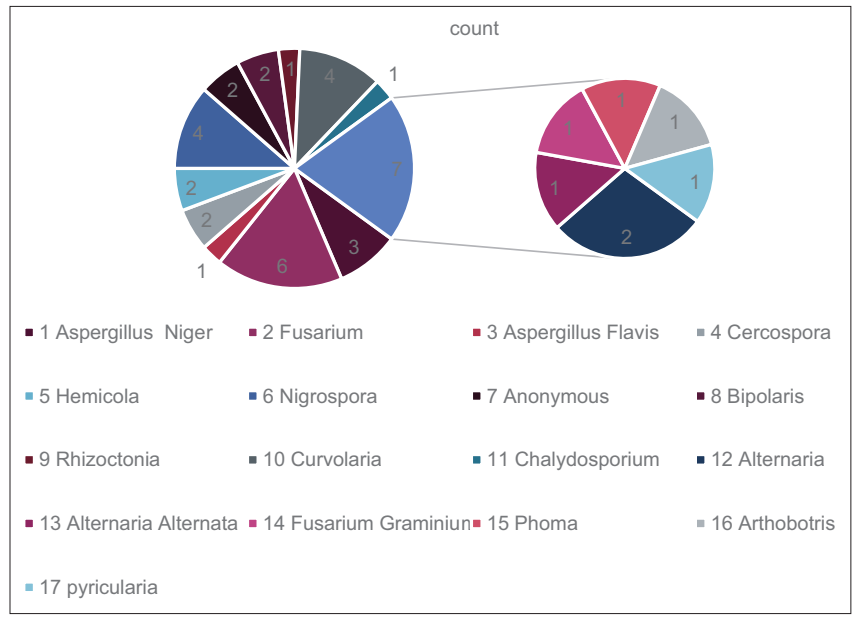

Graph 3: Counts of Different Rice Pathogen on Rice plant

which result in the collection characteristics seen in the laboratory. Fungi were frequently distinguished on the basis of conidiogenesis and other structures, that is, conidiophores and conidiogenous cells were also taken in account. Some fungi produce sporangia (sac-like cells), the whole protoplasm of which became slashed into spores called sporangiospores. On special hyphae called sporangiophores, sporangia were also observed.

Here are the following tables including Tables 1-3 in which the mycoflora of rice has been explored. The results has also been demonstrated in Graphs 1-3.

\section{CONCLUSION}

In most modern classifications, fungi are ranked, like plants and animals, as a separate kingdom. A bunch of related species is grouped in a genus, of related genera in families, of families in orders, orders in classes, and classes in subkingdoms. Zygomycotina, Ascomycotina, and
Deuteromycotina are the three subkingdoms of the kingdom fungi that include the most significant genera in food spoilage. Fungi from each of these subkingdoms have fairly separate properties, shared with other genera and species from the same subkingdom.

\section{REFERENCES}

1. Yoshinaga S, Takai T, Arai-Sanoh Y, Ishimaru T, Kondo M. Varietal differences in sink production and grain-filling ability in recently developed high-yielding rice (Oryza sativa L.) varieties in Japan. Field Crops Res 2013;150:74-82.

2. Memon NA. Rice: Important cash crop of Pakistan. Pak Food J 2013;2013:21-3.

3. Etesami H. Plant growth promotion and suppression of fungal pathogens in rice (Oryza sativa L.) by plant growth-promoting bacteria. In: Field Crops: Sustainable Management by PGPR. Cham: Springer; 2019. p. 351-83

4. Xu JR, Hamer JE. MAP kinase and cAMP signaling regulate infection structure formation and pathogenic growth in the rice blast fungus Magnaporthe grisea. Genes Dev 1996;10:2696-706.

5. Rehman FU, Adnan M, Kalsoom M, Naz N, Husnain MG, Ilahi H, et al Seed-borne fungal diseases of maize (Zea mays L.): A review. Agrinula 2021;4:43-60

6. Malaker PK, Mian IH, Bhuiyan KA, Akanda AM, Reza MM. Effect of storage containers and time on seed quality of wheat. Bangladesh J Agric Res 2008;33:469-77.

7. Harman GE, Howell CR, Viterbo A, Chet I, Lorito M. Trichoderma species-opportunistic, avirulent plant symbionts. Nat Microbiol 2004;2:43-56

8. Bashyal BM, Rawat K, Sharma S, Gogoi R, Aggarwal R. Major seedborne diseases in important cereals: Symptomatology, aetiology and economic importance. In: Seed-Borne Diseases of Agricultural Crops: Detection, Diagnosis and Management. Singapore: Springer; 2020. p. 371-426.

9. Kihoro J, Bosco NJ, Murage H, Ateka E, Makihara D. Investigating the impact of rice blast disease on the livelihood of the local farmers in greater Mwea region of Kenya. Springerplus 2013;2:1-3.

10. Shahjahan AK, Duve T, Bonman JM. Climate and Rice Diseases: Weather and Rice. Los Banon, Lequa, Philippines: IRRI; 1987. p. 125-8.

11. Berruyer R, Poussier S, Kankanala P, Mosquera G, Valent B Quantitative and qualitative influence of inoculation methods on in planta growth of rice blast fungus. Phytopathology 2006;96:346-55. 